DOI: 10.32844/2222-5374-2020-104-2.42

УДК: $343.72: 343.91$

Курята Л. Л., здобувач кафедри криміналістики та судової медицини Національної академії внутрішніх справ

\title{
КРИМІНАЛІСТИЧНИЙ «ПОРТРЕТ» ОСОБИ ЗЛОЧИНЦЯ, ЯКА ВЧИНЯЄ ШАХРАЙСТВА ПІД ПРИВОДОМ ПРОПОВІДУВАННЯ ВІРОВЧЕНЬ ТА ВИКОНАННЯ РЕЛІГІЙНИХ ОБРЯДІВ
}

Актуальність статті полягає в тому, що проблема шахрайства упродовж декількох десятиліть не втрачає своєї наукової актуальності та практичної значущості. Значна кількість наукових праць фахівців у галузі криміналістики, кримінології, кримінального права, кримінального процесу, юридичної психології, присвячена різним аспектам цього суспільно-небезпечного явища. Метою статті $\epsilon$ створення типового портрету особи, яка вчиняє шахрайства під приводом проповідування віровчень та виконання релігійних обрядів, на підставі виявлення та дослідження криміналістично значущих ознак, які формують категорію «особа злочинця». У статті досліджено загальні аспекти стосовно формування криміналістичного "портрету» особи, яка вчиняє шахрайства під приводом проповідування віровчень та виконання релігійних обрядів, та можливості його використання під час здійснення кримінального провадження. Визначено категорії криміналістичнозначущої інформащії, яка може бути використана в процесі вивчення особи злочинця, зокрема: демографічні відомості про особу шахрая; соціальні та психологічні ознаки шахрая; відомості про фізичні та фізіологічні особливості шахрая. Проведено диференціацію шахраїв на певні види, залежно від обраної сфери діяльності та способу шахрайських дій та виокремлено наступні групи: шахраї, які представляють різні релісійні культи, вчиняють антисоціальні дії, шляхом провокації масових заворушень, з метою введення потерпілих в оману та заволодіння їх матеріальними цінностями; шахраї, які очолюють закордонні релігійні представництва та їх дії спрямовані на отримання та використання у своїх цілях не задекларованих пожертв громадян; шахраї, які є лідерами або адептами неорелігійних груп закордонного походження та, з метою отримання матеріальних цінностей, використовують психологічний інструментарій для формування у потерпілих стійкої залежності від культу; шахраї, які дії яких, спрямовані на здійснення продажу адептам «неякісного товару» шляхом маніпулювання інформацією.

Ключові слова: шахрайство, особа злочинця, види шахраїв, релігія, віровчення, розслідування кримінальних правопорушень, кримінальне провадження. 
Актуальність теми. Проблема шахрайства упродовж декількох десятиліть не втрачає своєї наукової актуальності та практичної значущості. Значна кількість наукових праць фахівців у галузі криміналістики, кримінології, кримінального права, кримінального процесу, юридичної психології, присвячена різним аспектам цього суспільно-небезпечного явища.

Основними чинниками, які детермінують наукові дослідження у цій сфері $\epsilon$ розроблення дієвих механізмів, спрямованих на: своєчасне виявлення та фіксацію фактів вчинення шахрайських дій; встановлення особи-шахрая (шахраїв) та вжиття заходів спрямованих на припинення його (ïx) неправомірної діяльності; з'ясування тривалості такої «шахрайської діяльності», визначення кількості потерпілих та суми заподіяних збитків; забезпечення повернення майна, належного потерпілій (потерпілим) особі (особам) та відшкодування заподіяної матеріальної шкоди, тощо.

Згідно з даними Єдиного звіту про кримінальні правопорушення Офісу Генерального прокурора, протягом 2019 року зареєстровано 444,1 тис. кримінальних правопорушень, з яких 256,5 тис. (57,8 \%) - злочини проти власності, 3 них 32,4 тис. (12,6 \%) - шахрайства; у 2020 році - 360,6 тис. кримінальних правопорушень, з яких 189,1 тис. (52,5 \%) - злочини проти власності, 26,8 тис. (14,1 \%) - шахрайства. Упродовж першого кварталу 2021 року - 106,5 тис. кримінальних правопорушень, з яких 54,3 тис. $(50,9 \%)$ - злочини проти власності, 5,2 тис. $(9,6 \%)$ - шахрайства [13] ${ }^{1}$.

Наведені статистичні дані підтверджують недостатню ефективність засобів і методів, які використовують у протидії зазначеній категорії злочинів. Водночас, з огляду на надзвичайно високу латентність шахрайства $€$ достатні підстави вважати, що цей показник $є$ значно вищим, що зумовлює необхідність розробки та впровадження у правоохоронну практику нових дієвих інструментів, які дозволять забезпечити реалізацію головних принципів кримінального провадження.

Метою статті $\epsilon$ створення типового портрету особи, яка вчиняє шахрайства під приводом проповідування віровчень та виконання релігійних обрядів, на підставі виявлення та дослідження криміналістично значущих ознак, які формують категорію «особа злочинця».

Виклад основного матеріалу. Особа злочинця, безперечно, є центральним елементом криміналістичної характеристики та фактично являє собою генезис виникнення злочину, оскільки злочин, будучи результатом свідомої вольової діяльності людини, не тільки не може існувати поза особою, яка його вчинила, а й в більшій мірі обумовлюється сутністю і особливостями цієї особи [1, с. 239].

Особливістю шахрайства $\epsilon$ те, що шахрай викликає у потерпілого спонукання, бажання передати йому майно чи уступити право на майно. Введений в оману, потерпілий сам добровільно передає винному майно чи право на нього [2, с. 147].

Дослідженням актуальних проблем, пов'язаних із методикою розслідування кримінальних правопорушень, формуванням криміналістичної

${ }^{1}$ Єдиний звіт про кримінальні правопорушення. Форма № 1 (місячна) : наказ Генеральної прокуратури України від 23 жовт. 2012 p. № 100. URL: https://www. gp.gov.ua/ua/ stat_n_st?dir_id=113653\&libid=100820\&c=edit\&_c=fo. 
характеристики злочинів та її структурним наповненням кількісними та якісними елементами, в тому числі наукової категорії «особа злочинця», займались провідні вчені, зокрема: Ю. П. Аленін, В. П. Бахін, Р. С. Бєлкін, Л. В. Васильєв, М. Т. Ведерников, П. С. Дагель, М. М. Демідов, А. В. Дулов, В. Ф. Єрмолович, Н. І. Клименко, В. О. Коновалова, А. С. Кривошеєв, Г. К. Курашвілі, Н. С. Лейкіна, І. А. Матусевич, С. Ф. Мілюков, К. К. Платонов, О. Р. Ратинов, М. В. Салтевський, С. С. Степичев, В. В. Тіщенко, Л. Д. Удалова, С. С. Чернявський, Ю. М. Чорноус, В. Ю. Шепітько та інші.

Зусиллями значної кількості дослідників у різних галузях права, здійснено колосальний внесок щодо висвітлення проблемних та актуальних питань такої складної категорії як «особи злочинця-шахрая». Водночас аналіз наявних методичних та практичних рекомендацій щодо розслідування шахрайств, дозволяє дійти висновку, що до теперішнього часу окремого комплексного дослідження, присвяченого проблемам розслідування шахрайств, вчинених під приводом проповідування віровчень та виконання релігійних обрядів не здійснено. В тому числі донині відсутні методики криміналістичного профайлінгу стосовно особи, яка вчиняє шахрайство під приводом проповідування віровчень та виконання релігійних обрядів, що безумовно обмежує можливості своєчасного виявлення, документування та ефективного розслідування злочинів зазначеної категорії.

Ю. І. Азаров, у структурі характеристик особи злочинця виокремлював наступні елементи: 1) ступінь суспільної небезпечності особи; 2) індивідуально обумовлені ознаки особистості обвинуваченого; 3) соціально обумовлені ознаки особи; 4) біолого-психологічні риси особи; 5) дані про ставлення обвинуваченого до вчиненої ним злочинної дії та його поведінка під час розслідування [3, с. 15-16].

М. М. Демідов під особою злочинця як елемента криміналістичної характеристики розуміє стійку криміналістично значиму сукупність психофізичних властивостей і якостей, мотиваційних установок, емоційної і раціональної сфер людської свідомості, що відобразились у слідах злочину в процесі підготовки, вчинення і приховання слідів злочину, а також поведінки після вчинення злочину [4, с. 87].

К. К. Платонов пропонував характеризувати особу за чотирма основними критеріями: 1) соціально-обумовлені особистісні риси особи злочинця; 2) життєвий або професійний досвід особи; 3) риси, що відтворюють індивідуальні особливості психічних процесів; 4) сукупність типологічних властивостей нервової системи, а також статевих і вікових особливостей [5, с. 68].

М. В. Салтевський стверджував, що характеристика особи злочинця повинна давати опис людини як соціально-біологічної системи, властивості й ознаки якої відображаються в матеріальному середовищі та використовуються для розслідування злочинів. До таких властивостей людини належать фізичні, біологічні й соціальні [6, с. 422].

На нашу думку, наведені вище пропозиції безперечно є слушними, а їх урахування під час розслідування дозволить забезпечити отримання інформації орієнтуючого та доказового характеру не тільки відносно особи, але і стосовно інших кореляційно-пов'язаних із цією категорією елементів криміналістичної характеристики. 
Особа шахрая значно відрізняється від особи інших злочинців (злодіїв, грабіжників, хуліганів), незважаючи на зовнішню схожість багатьох характеристик. Як правило шахраям притаманний хитрий розум, акторські здібності, розвинена фантазія, уміння орієнтуватися в складній обстановці та уміння використовувати обстановку на свою користь. Здебільшого шахраями є особи, які мають певні знання з психології людини. Шахраєві властивий розвинений інтелект, сила переконання, витончена наполегливість в реалізації злочинного задуму. Вивчення особи шахрая свідчить про їх високий професіоналізм, вузьку спеціалізацію, досить широкий кругозір, правові знання [7, с. 21].

В. Ю. Шепітько визначає, що особі шахрая, притаманний комплекс специфічних ознак, зокрема: сильний дар уяви, використання впливу і вміння переконувати людей [8, с. 144].

Аналогічну позицію висловлює М. С. Жилкіна, яка зазначає, що особа шахрая досить специфічна з огляду на психологічні якості та особливості, зокрема: дар переконувати; уміння викликати довір'я та повагу у представників різних вікових, соціальних та психологічних груп; адаптивність і гнучкість; уміння швидко реагувати на зміну обстановки; схильність до ризику (так званий «азарт гравця» - бажання «переграти» опонента); знижене почуття тривожності; високий самоконтроль тощо [9, c. 131-132].

За результатами нашого дослідження, із урахуванням окремих положень криміналістичного профайлінгу, який являє собою певну сукупність методів оцінки та прогнозування поведінки особи на підставі аналізу найбільш інформативних індивідуальних ознак, характеристик зовнішності, вербальної та невербальної поведінки, ми дійшли висновків, що найбільш криміналістично-значущими категоріями, які дозволять дослідити особу, який вчиняє шахрайські дії під приводом проповідування віровчень та виконання релігійних обрядів, та скласти її узагальнений криміналістичний «портрет» $\epsilon:$ 1) демографічні ознаки; 2) соціальні ознаки; 3) психологічні ознаки; 4) фізичні та фізіологічні ознаки.

За результатами узагальнення судової практики, можливо диференціювати шахраїв на певні типи: випадкові шахраї, що здійснюють шахрайство уперше по легковажності, під впливом обставин або інших осіб; шахраї-рецидивісти, що здійснюють головним чином дрібні шахрайські витівки (як правило це раніше судимі раніше судимі за шахрайство та інші особи, що не мають постійного джерела доходу); шахраї - багатократні рецидивісти; шахраї-гастролери; шахраї, що здійснюють «шахрайство, яке триває» (по суті така незаконна діяльність зводиться до постійного отримання яких-небудь або будь-яких матеріальних благ); шахраї-аферисти або шахраї-професіонали (спосіб життя таких осіб пов'язаний із систематичним здійсненням злочинів, які є для них основним джерелом отримання коштів для існування) [10, с. 51].

В контексті досліджуваного різновиду шахрайств, слід відмітити, що особам, які вчиняють шахрайські дії під приводом проповідування віровчень та виконання релігійних обрядів притаманний професійний підхід до вчинення злочину, оскільки спосіб їх реалізації передбачає системний підхід та тривалий характер підготовки до досягнення злочинної мети. 
Загалом, такі особи характеризуються наступним чином: це жінки або чоловіки, віком 30-50 років, які мають середню-спеціальну або вищу освіту, досить високий інтелектуальний рівень, добре володіють умінням швидко орієнтуватись у ситуації, мають навички психологічного впливу та впевнено користуються довірливістю громадян.

На підставі обраної сфери діяльності та способу шахрайських дій, можливо класифікувати осіб, які вчиняють шахрайські дії під приводом проповідування віровчень та виконання релігійних обрядів, за наступними різновидами:

- шахраї, які представляють різні релігійні культи, вчиняють антисоціальні дії, шляхом провокації масових заворушень, з метою введення потерпілих в оману та заволодіння їх матеріальними цінностями;

- шахраї, які очолюють закордонні релігійні представництва та їх дії спрямовані на отримання та використання у своїх цілях не задекларованих пожертв громадян;

- шахраї, які є лідерами або адептами неорелігійних груп закордонного походження та, з метою отримання матеріальних цінностей, використовують психологічний інструментарій для формування у потерпілих стійкої залежності від культу;

- шахраї, які дії яких, спрямовані на здійснення продажу адептам «неякісного товару» шляхом маніпулювання інформацією.

Окремої уваги, заслуговують ознаки шахрая, які характеризують таких осіб з точки зору вміння маніпулювати свідомістю людей та використовувати засоби психологічного впливу для досягнення злочинної мети.

Психологічна характеристика особи-шахрая базується на концепції, яка запропонована юридичною психологією та згідно якої в основі відмінностей особи злочинця від правосвідомих громадян лежать ціннісні орієнтації, дефекти правосвідомості та злочинні наміри. 3 позицій юридичної психології в особі шахрая, виділяються такі основні групи чинників, що впливають на формування злочинної поведінки: ядро особи, ціннісні орієнтації, дефекти правосвідомості, установки, мотиви, вивчення і дослідження яких, на жаль, вислизає від учених, що вивчають особу злочинця нині. На специфіку ціннісних орієнтацій шахрая вказує той факт, що він відноситься до жертви як до неживого об'єкта. Людина для нього насамперед - це можливе джерело власних матеріальних благ. Внутрішній світ жертви, їі переживання, страждання у разі позбавлення матеріальних цінностей для злочинця не мають значення. У шахрайських посяганнях на перший план виступає яскраво виражений корисливий мотив. Проте, окрім користі, мотивами шахрайської діяльності можуть бути: самоствердження, приховане прагнення до влади [11, с. 32].

Також до характерних психологічних рис особи шахраїв можна віднести: дар переконання; вміння викликати довіру чи повагу (довіру - через симпатію, повагу і страх - через ілюзію сили); адаптивність і гнучкість; вміння працювати з інформацією та швидке реагування на мінливу інформацію; вміння планувати, обмірковувати все до дрібниць; схильність до ризику; знижена тривожність; високий самоконтроль, самовладання, терпіння та ін. [12, с. 156]

Враховуючи викладене, не викликає сумніву, що використання типового психологічного портрету сучасного шахрая, в тому числі яких вчиняє 
шахрайські дії під приводом проповідування віровчень та виконання релігійних обрядів, допомагає забезпечити ефективне розслідування.

Висновки. За результатами дослідження, з'ясовано, що типовою особою, яка вчиняє шахрайські дії під приводом проповідування віровчень та виконання релігійних обрядів є жінки або чоловіки, віком 30-50 років, які мають середню-спеціальну або вищу освіту, досить високий інтелектуальний рівень, добре володіють умінням швидко орієнтуватись у ситуації, мають навички психологічного впливу та впевнено користуються довірливістю громадян. Таких осіб, залежно від обраного ними способу злочинної діяльності, можливо диференціювати на наступні категорії: шахраї, які представляють різні релігійні культи, вчиняють антисоціальні дії, шляхом провокації масових заворушень, з метою введення потерпілих в оману та заволодіння їх матеріальними цінностями; шахраї, які очолюють закордонні релігійні представництва та їх дії спрямовані на отримання та використання у своїх цілях не задекларованих пожертв громадян; шахраї, які $\epsilon$ лідерами або адептами неорелігійних груп закордонного походження та, з метою отримання матеріальних цінностей, використовують психологічний інструментарій для формування у потерпілих стійкої залежності від культу; шахраї, які дії яких, спрямовані на здійснення продажу адептам «неякісного товару» шляхом маніпулювання інформацією.

Із урахуванням запропонованих положень, які стосуються характеристики особи, що вчиняє шахрайські дії під приводом проповідування віровчень та виконання релігійних обрядів, можливо не лише дослідити особу шахрая, але і побудувати типові версії її поведінки, своєчасно визначити час та місце вчинення злочину, викрити послідовників такої діяльності, а також забезпечити повноту та всебічність розслідування.

\section{СПИСОК ВИКОРИСТАНИХ ДЖЕРЕЛ}

1. Курята Л.Л. Криміналістична характеристика особи, яка вчиняє шахрайство Актуальні проблеми криміналістики та судової експертології. 2018. С. 239-241.

2. Курята Л.Л. Криміналістична характеристика розслідування шахрайства, вчиненого під приводом проповідування віровчень та виконання релігійних обрядів та її значення для розслідування. Науковий вісник публічного та приватного права. 2017. Вип. 6. Т. 3. С. 145-148.

3. Азаров Ю. И. Деятельность следователя органов внутренних дел по доказыванию обстоятельств, характеризующих личность обвиняемого / отв. ред. А. Я. Дубинский. Киев : НИ И РИО, 1991. 80 с.

4. Демидов Н.Н. Изучение личности преступника в процессе расследования : дисс. ... к.ю.н.: 12.00.09. Волгоград, 2003. С. 187.

5. Платонов К. К. Психологическая структура личности. Личность при социализме. М., 1969. С. 62-68.

6. Салтевський М. В. Навчально-довідковий посібник з криміналістики. Київ, 1994. 180 с.

7. Попов С. Зловживання довірою при шахрайстві. Кримінальне право. 2004. № 9. С. 21-25.

8 Шепітько В. Ю. Особливості криміналістичної характеристики шахрайства. Вісник Академії правових наук України. Харків, 1998. № 2. С. 144. 
9. Жилкина М. С. Страховое мошенничество: Правовая оценка, практика выявления и методы пресечения. Москва, 2005. С. 192.

10. Волженкин Б. В. Мошенничество. Современные стандарты в уголовном праве и уголовном процессе. 1998. С. 20-25.

11. Прудка Л. М Психологічні особливості шахрайства в мережі інтернет. Південноукраїнський правничий часопис. Протидія злочинності: проблеми практики та науково-методичне забезпечення. 2-2018. с.31-33 303 c.

12. Кравченко О.В. Психологічні особливості шахрая. Х.: «Право», 2005.

13. Єдиний звіт про кримінальні правопорушення. Форма № 1 (місячна) : наказ Генеральної прокуратури України від 23 жовт. 2012 р. № 100. URL: https://www.gp.gov.ua/ua/ stat_n_st?dir_id=113653\&libid=100820\&c=edit\&_ $\mathrm{c}=$ fo.

\section{Kuriata}

\section{CRIMINAL «PORTRAIT» OF THE PERSON OF THE CRIMINAL, COMMITTING FRAUD DUE TO PREACHING RELIGIONS AND PERFORMANCE OF RELIGIOUS RITUALS}

The relevance of the article is that the problem offraud has not lost its scientific relevance and practical significance for several decades. A large number of scientific works of specialists in the field of criminology, criminology, criminal law, criminal procedure, legal psychology, devoted to various aspects of this socially dangerous phenomenon. The aim of the article is to create a typical portrait of a person who commits fraud under the pretext of preaching doctrines and performing religious rites, based on the identification and study of forensic features that form the category of "criminal person". The article examines the general aspects of the formation of a forensic "portrait" of a person who commits fraud under the pretext of preaching doctrines and performing religious rites, and the possibility of its use in criminal proceedings. The categories of forensically significant information that can be used in the process of studying the identity of the offender, in particular: demographic information about the identity of the scammer; social and psychological signs of a scammer; information about the physical and physiological characteristics of the scammer. Fraudsters have been differentiated into certain types, depending on the chosen field of activity and method of fraudulent activities, and the following groups have been identified: fraudsters representing various religious cults, committing antisocial actions by provoking mass riots, in order to mislead victims and seize their material possessions; fraudsters who head foreign religious missions and their actions are aimed at receiving and using for their purposes undeclared donations of citizens; fraudsters who are leaders or adherents of neo-religious groups of foreign origin and, in order to obtain material values, use psychological tools to form in the victims a stable dependence on the cult; fraudsters, whose actions are aimed at selling to adherents of "substandard goods" by manipulating information.

Keywords: fraud, identity of the criminal, types of fraudsters, religion, doctrine, investigation of criminal offenses, criminal proceedings. 